\title{
Experimental Study on Impermeability of Concrete Mixed with Limestone Powder
}

\author{
Junfang HUO \\ School of Civil Engineering \\ Inner Mongolia University of Technology \\ Hohhot 010051, China \\ Jian WEI \\ School of Civil Engineering \\ Inner Mongolia University of Technology \\ Hohhot 010051, China
}

\author{
Shaoyu ZHANG \\ School of Civil Engineering \\ Inner Mongolia University of Technology \\ Hohhot 010051, China \\ E-mail: 2430784133@qq.com
}

\author{
Hua PAN \\ China Building Materials Academy \\ Beijing 100024, China
}

\begin{abstract}
Limestone powder as a concrete admixture was incorporated into the concrete, mechanical properties and impermeability of concrete were studied, and influence mechanism of concrete was analyzed. Experimental results showed workability of concrete was improved when appropriate proportion limestone powder mixed into concrete. Concrete 3d, 7d, 28d compressive strength increased when $10 \%, 20 \%$ limestone powder were mixed into concrete. Compressive strength with $30 \%$ limestone powder descended.
\end{abstract}

\section{Keywords-limestone powder; concrete; impermeability}

\section{INTRODUCTION}

In recent years, water conservancy, communications, civil and engineering construction scale is unprecedented, in some regions of high quality fly ash supply shortage, especially for the southwest region the situation is even more prominent, the long-distance transportation of fly ash will increase the production cost of the concrete. Looking for a nearby draw materials, quality and cheap new mineral admixture synthetic material imminent[1], limestone powder is a kind of easy grinding, low price, convenient transportation of materials[2],for it is of great practical significance to solve the practical engineering of raw materials shortage, engineering cost and other aspects of environmental protection. This research mainly increase with ground limestone content, lime powder effect on concrete mechanical properties and impermeability of and the influence mechanism was analyzed.

\section{EXPERIMENTAL DESIGN}

The Index of Raw Materials and Performance Test

Cement: Test of cement used for the production of the swan of Harbin Yatai group cement production grade 42.5 composite Portland cement, the specific performance is shown in Tab. 1.
Coarse aggregate: The coarse aggregate is gravel, graded $5-25 \mathrm{~mm}$ continuous particle size,

The specific performance is shown in Tab. 2 .

Fine aggregate: In the sand, particle size distribution is good, mud content is $2 \%$, the apparent density of $2650 \mathrm{~kg} / \mathrm{m} 3$, the bulk density is $1465 \mathrm{~kg} / \mathrm{m} 3$, the fineness modulus of 2.5 .

Limestone powder: The limestone of Hebei Tian Hao Lingshou mineral processing plant to produce 400 orders (38 $\mathrm{m})$ limestone, the specific performance is shown in Tab. 3,4.

Admixture: Used in the test for the Heilongjiang Yongji admixture building materials Co. Ltd. production water reducing FDN-Y, water reduction rate of $16 \%$, gas $1.2 \%$.

Water: The test uses ordinary tap water

The Test Mix

Test of concrete strength grade of C30, comparison of the different content of the single case of limestone powder. According to the standard Specification for mix proportion design of ordinary concrete JGJ55-2000 to design with the ratio of concrete mixture ratio design in accordance with the good production of concrete, various amount of specimen number, mix design is shown in tab. 5 .

\section{COMPARATIVE ANALYSIS OF TEST RESUlts}

The Influence of Limestone Powder on Compressive Strength of Concrete

The research object of this test for C30 concrete, according to the standard Specification for mix proportion design of ordinary concrete JGJ55-2000 test method for compressive strength of concrete cubes prescribed in the test, the test of concrete cube specimens with the size of $150 \mathrm{~mm} \times 150 \mathrm{~mm} \times 150 \mathrm{~mm}$, The test results are shown in tab. 6:

From tab. 6 can be obviously seen, when to use limestone powder quality instead of $10 \%$ of cement, concrete compressive strength of concrete $3 \mathrm{~d}, 7 \mathrm{~d}$ and $28 \mathrm{~d}$ compressive strength were increased by $6.4 \%, 3 \%, 7 \%$, and lime stone powder content is $20 \%$, a further increase in the 
strength of concrete, respectively, an increase of the $12.7 \%$, $5.3 \%, 12.4 \%$. Enhancing effect of limestone powder on the strength of concrete is mainly because the micro aggregate effect and the nuclear effects of limestone. Concrete may be regarded as a continuous gradation of particles accumulation system, the small particles filled the gap between large particles, the fineness of limestone powder ratio of cement particles to much thinner. Can fill the gap between the cement particles, improve the concrete pore structure[3], to make concrete more dense, and thus the strength increased; limestone powder crystal nucleus effect mainly, lime stone powder can make C-S-H and calcium hydroxide attached in the surface of $\mathrm{CaCO}_{3}$ particles and prevent $\mathrm{Ca}(\mathrm{OH})_{2}$ in cement paste and aggregate interface grow into large crystals, and enhance the interfacial bonding, while reducing the ion concentration in liquid phase, accelerated the hydration of $\mathrm{C}_{3} \mathrm{~S}$, is conducive to the growth of the strength of concrete, so as to improve the strength of cement stone[4].

When up to 28 days of age, compared with limestone powder admixture for concrete with $0 \%$, when the lime powder quality replacing cement by $10 \%$, the compressive strength of concrete is rising to a certain extent, instead of $20 \%$ of cement, concrete compressive strength increase rate decreased slightly, that limestone powder have certain activity, but the activity of cement compared to small.

When in the concrete mixed with $30 \%$ lime mixed stone powder content, concrete 3 days, 7 days and 28 days compressive strength were reduced by $9.3 \%, 3.4 \%$ and $8.5 \%$. Is mainly due to two reasons. One is due to too much content into superfine mineral admixture admixture will have a negative effect, because the surface area of the ultrafine powder is so big that will increase the adsorption force between the particle surface, making ultrafine particles cling together and difficult floc, resulting in superfine mineral admixture admixture cannot be filled uniformly into the coarse and fine aggregate, intermediate, so that the internal structure of concrete pore increased, reduced density affects the development of the compressive strength performance. Second is incorporation of a small amount of limestone powder in concrete can effectively improve the concrete of particle size and distribution, but in concrete incorporation of excess lime stone powder can not only improve the bulk density, but also reduce the strength of concrete interior skeleton structure. Due to the limestone equivalent replacement of cement, when mixing with limestone powder more, concrete can participate in the hydration reaction of cement amount less the concrete cementitious material shortage and activity of the powder is low, resulting in a decline in the strength of the concrete.

The test results show that when the lime powder quality to replace cement mixing, compared the content of limestone powder 28 days old $10 \%$ concrete and limestone powder content is $0 \%$, the concrete seepage height decreased by $8.9 \%$, thus replacing part of cement with a small amount of lime powder can effectively improve the concrete quality. The anti permeability performance. This is because the morphology effect of limestone powder has its own effect and activity play a role. Limestone particle size ratio of cement particles should be small, can regard it as a kind of micro aggregate, which can be easily dispersed into the void of cement particles, the concrete particle gradation optimization and dense pore structure inside, the aggregate accumulation system is changed uniformly so that the concrete structure more compact. $\mathrm{CaCO}_{3}$ and lime can and cement hydration reaction of $\mathrm{Ca}(\mathrm{OH})_{2}$ reacted basic calcium carbonate filled in the transition zone of interface transition layer structure, further increase the compactness of the concrete pore reduced.

Compared with the dosages of $20 \%$ and $30 \%$ of concrete and limestone powder content is $0 \%$, the increase in the height of the concrete seepage, seepage height were increased by $24.4 \%$ and $80.3 \%$. Mainly due to the large number of limestone powder replacing cement, the cement stone components reduction, hydration products and the corresponding reaction is reduced, so that in the same other conditions, the structure of cement stone is loose. And limestone powder has low activity, reduce the hydration process, thus reduce the bonding performance between cement paste and aggregate, and limestone powder. When the proportion is too large, there will be a part of limestone powder did not participate in the hydration reaction gathered around the aggregate, because of its good "ball" effect, thus reducing friction between the aggregate, reduces the connection between cement paste and aggregate and destroy the properties of transition layer, so the incorporation of excess limestone will make the impermeability of concrete deterioration.

\section{CONCLUSION}

(1) Influence of limestone powder on compressive strength of concrete with different concrete age and different, the effect on the compressive strength of concrete early is obvious.

(2)When the lime stone powder in mixed, the incorporation of $10 \%, 20 \%$ of the lime stone powder can enhance the value of the compressive strength of concrete at early and late, but when the $30 \%$ limestone flour mixed into concrete, the compressive strength of concrete at early and late values were significantly reduced.

(3) With appropriate amount of lime stone powder doped mixed into concrete can to some extent improve the impermeability, when the lime powder replacing cement quality has reached $10 \%$, concrete anti seepage highly reduced $8.9 \%$. When the content of limestone powder to increase to $20 \%$ and $30 \%$, anti permeability decreases with the increase in volume of concrete.

\section{ACKNOWLEDGMENTS}

Financial Support: Project in the National Science\& Technology Pillar Program during the 12th Five-year Plan Period (2014BAL03B04).

\section{REFERENCES}

[1] Yang Liu, Song Shaomin. Limestone powder and the influence of mineral admixture admixture on the workability and compressive strength of concrete $[\mathrm{J}]$. journal of beijing institute of civil engineering and architecture,2010,26(2):49-52. 
[2] Zhou Yongxiang, Wang Yonghai et al. The characteristic of limestone powder and the influence on concrete performance [J]. construction technique, 2014,43(9):23-27

[3] Xiao Fei et al. Study of ultra fine limestone powder of high strength concrete performance [J]. Silicate Bulletin, 2010,29(6):1303-1307
[4] He Jinyun et al. Study on the content of limestone powder on concrete performance $[\mathrm{J}]$. Journal of Hebei University of Engineering,2014,31(3):15-16

TABLE I. PERFORMANCE INDEX OF P.O 42.5 CEMENT

\begin{tabular}{|c|c|c|c|c|c|}
\hline $\begin{array}{c}\text { Strength grade of } \\
\text { cement }\end{array}$ & Stability & $\begin{array}{l}\text { The initial } \\
\text { setting time } \\
\text { (min) }\end{array}$ & $\begin{array}{c}\text { final setting } \\
\text { time } \\
(\mathrm{min})\end{array}$ & $\begin{array}{c}\text { compressive } \\
\text { strength }(\mathrm{MPa})\end{array}$ & $\begin{array}{c}\text { Flexural } \\
\text { strength }(\mathrm{MPa})\end{array}$ \\
\hline \multirow{2}{*}{$\mathrm{P} \cdot \mathrm{O} 42.5$} & \multirow{2}{*}{ qualified } & \multirow{2}{*}{165} & \multirow{2}{*}{226} & $28 \mathrm{~d}$ & $28 \mathrm{~d}$ \\
\hline & & & & 21.9 & 4.8 \\
\hline
\end{tabular}

TABLE II. GRAVEL PHYSICAL PERFORMANCE INDEX

\begin{tabular}{ccccc}
\hline gradation & $\begin{array}{c}\text { Needle and flake } \\
\text { content }(\%)\end{array}$ & The mud content $(\%)$ & Clay content $(\%)$ & Crush index value $(\%)$ \\
\hline $5-25 \mathrm{~mm}$ & 3 & 0.2 & 0.2 & 3.7 \\
\hline
\end{tabular}

TABLE III. LIMESTONE POWDER PHYSICAL INDICATORS

\begin{tabular}{|c|c|c|c|c|}
\hline particle size & Micron number & $\begin{array}{l}\text { specific surface } \\
\operatorname{area}(\mathrm{m} 2 / \mathrm{kg})\end{array}$ & $\begin{array}{c}0.045 \mathrm{mmSieve} \text { residue } \\
(\%)\end{array}$ & $\begin{array}{c}\text { Methylene blue } \\
\text { value }(\mathrm{g} / \mathrm{kg})\end{array}$ \\
\hline 400 & $38 \mu \mathrm{m}$ & 223 & 35.1 & 1.0 \\
\hline
\end{tabular}

TABLE IV. LIMESTONE POWDER CHEMICAL COMPOSITION

\begin{tabular}{ccccc}
\hline $\mathrm{SiO}_{2}$ & $\mathrm{Al}_{2} \mathrm{O}_{3}$ & $\mathrm{Fe}_{2} \mathrm{O}_{3}$ & $\mathrm{CaO}$ & $\mathrm{MgO}$ \\
\hline 85.16 & 0.06 & 7.04 & 0.56 & 1.10 \\
\hline
\end{tabular}

TABLE V. Mix PROPORTIONS OF CONCRETE

\begin{tabular}{|c|c|c|c|c|c|c|c|c|c|}
\hline \multirow[b]{2}{*}{ Number } & \multirow[b]{2}{*}{$\begin{array}{l}\text { Mineral } \\
\text { admixture }\end{array}$} & \multirow[b]{2}{*}{ Volume } & \multirow[b]{2}{*}{$\begin{array}{l}\text { water to } \\
\text { binder } \\
\text { ratio }\end{array}$} & \multicolumn{6}{|c|}{$\begin{array}{l}\text { The amount of per cubic meter of concrete materials / } \\
\qquad \mathrm{kg}\end{array}$} \\
\hline & & & & cement & $\begin{array}{c}\text { Lime } \\
\text { stone } \\
\text { powder }\end{array}$ & sand & stone & Water & $\begin{array}{l}\text { water } \\
\text { reduc } \\
\text { er }\end{array}$ \\
\hline $\mathrm{A} 0$ & $\begin{array}{l}\text { The } \\
\text { referencer } \\
\text { group }\end{array}$ & $0 \%$ & 0.45 & 413 & 0 & 720 & 1081 & 186 & 12.39 \\
\hline $\mathrm{A} 1$ & $\begin{array}{l}\text { Lime stone } \\
\text { powder }\end{array}$ & $10 \%$ & 0.45 & 371.7 & 41.3 & 720 & 1081 & 186 & 12.39 \\
\hline $\mathrm{A} 2$ & $\begin{array}{l}\text { Lime stone } \\
\text { powder }\end{array}$ & $20 \%$ & 0.45 & 330.4 & 82.6 & 720 & 1081 & 186 & 12.39 \\
\hline $\mathrm{A} 3$ & $\begin{array}{l}\text { Lime stone } \\
\text { powder }\end{array}$ & $30 \%$ & 0.45 & 289.1 & 123.9 & 720 & 1081 & 186 & 12.39 \\
\hline
\end{tabular}


TABLE VI.

THE COMPRESSIVE STRENGTH OF CONCRETE

\begin{tabular}{cccccc}
\hline \multirow{2}{*}{ Number } & $\begin{array}{c}\text { Mineral } \\
\text { additives form }\end{array}$ & Admixture\% & \multicolumn{3}{c}{$\begin{array}{c}\text { compressive } \\
\text { strength /MPa }\end{array}$} \\
\cline { 4 - 6 } A0 & $\begin{array}{c}\text { The reference } \\
\text { group } \\
\text { Lime stone } \\
\text { powder }\end{array}$ & 0 & $3 \mathrm{~d}$ & $7 \mathrm{~d}$ & $28 \mathrm{~d}$ \\
$\mathrm{~A} 1$ & 10 & 18.3 & 26.5 & 35.4 \\
$\mathrm{~A} 2$ & $\begin{array}{c}\text { Lime stone } \\
\text { powder } \\
\text { Lime stone } \\
\text { powder }\end{array}$ & 20 & 19.4 & 27.3 & 37.9 \\
$\mathrm{~A} 3$ & 30 & 15.6 & 27.9 & 39.8 \\
\hline
\end{tabular}

TABLE VII. ANTI-PERMEABILITY TEST RESULTS OF CONCRETE

\begin{tabular}{ccccccccc}
\hline \multirow{2}{*}{ Number } & $\begin{array}{c}\text { The content } \\
\text { oflimeston } \\
\text { powder }\end{array}$ & 1 & 2 & 3 & 4 & 5 & 6 & $\begin{array}{c}\text { average } \\
\text { value }\end{array}$ \\
\cline { 3 - 9 } & 0 & 11.4 & 6.7 & 23.5 & 31.8 & 40.7 & 14.2 & 21.3 \\
A0 & 10 & 30.6 & 12.3 & 8.4 & 22.5 & 13.7 & 29.1 & 19.4 \\
A1 & 20 & 15.4 & 25.7 & 32.3 & 44.6 & 23.8 & 17.2 & 26.5 \\
A2 & 30 & 55.2 & 24.5 & 29.6 & 45.8 & 49.7 & 25.6 & 38.4 \\
A3 & & & & &
\end{tabular}

